 \\ Паремии с компонентом-агиоантропонимом в испанском языке как элемент лингвокультурной картины мира
}

\author{
Захарова Л. Б., Захарова Е. В.
}

\begin{abstract}
Аннотация. Цель исследования - проанализировать лингвокультурные особенности паремий с агиоантропонимами. В статье определено понятие «паремия», ее виды, изучена проблема ономастического статуса и характеристики агиоантропонимов (в русском и испанском языках). Научная новизна заключается в примененном подходе рассмотрения широкого спектра паремиологических единиц с компонентом-агиоантропонимом, позволяющим установить их происхождение, коннотации, трансформации. В результате доказано, что характеристиками агиоантропонимов являются трехкомпонентная структура, наличие одного референта, прецедентность (сверхличностный характер), а также значимость референта для лингвокультуры.
\end{abstract}

\section{Paroemias with Agioanthroponym Component in Spanish as an Element of Linguocultural Worldview}

\author{
Zakharova L. B., Zakharova E. V.
}

\begin{abstract}
The aim of the research is to analyse the linguocultural characteristics of paroemias with hagioanthroponyms. The article defines the notion of "paroemia", its types, studies the problem of onomastic status and characteristics of hagioanthroponyms (in the Russian and Spanish languages). The scientific originality lies in the applied approach of considering a wide range of paroemiological units with an agioanthroponym component, which makes it possible to ascertain their origin, connotations and transformations. As a result, it has been proved that the characteristics of hagioanthroponyms are a three-component structure, the presence of one referent, precedence (superpersonal character), as well as the significance of the referent for linguistic culture.
\end{abstract}

\section{Введение}

Актуальность исследования паремий объясняется тем, что, несмотря на большое количество работ по данному вопросу, до сих пор не существует единого определения и классификации паремий, также лингвисты расходятся в вопросе о том, к какой области относится паремия. Безусловно, паремия рассматривается как часть фольклора. В последнее время многие отечественные лингвисты также вносят ее в состав фразеологии (А. В. Кунина), некоторые исследователи (В. Н. Телия, Н. Н. Амосова, А. М. Бабкин) выступают против отнесения паремии к этому разделу лингвистики (Шайхуллин, 2017).

Кроме того, тема паремии является важной и актуальной, потому что пословицы и поговорки отражают видение народом, объединенным общей культурой, картины мира, его отношение к различным явлениям и проблемам, обобщают в единое целое и образно оформляют мысли народа по разным вопросам (Рыбникова, 1961). Поэтому изучение паремий имеет непосредственную связь с изучением культуры, истории, языковой картины мира народа.

Интерес к исследованию паремий сформировался в 70-е гг. XX века после большого перерыва из-за утери термином своего исконного значения, связанного с религиозными текстами, и признания этого значения архаичным. Проблема определения и классификации различных устойчивых выражений, таких как поговорки, фразеологизмы и т.д., активно разрабатывалась в лингвистике в 60-80-х годах в работах В. В. Виноградова, В. Л. Архангельского, А. М. Бабкина, Б. А. Ларина, М. М. Копыленко, 3. Д. Поповой, А. И. Федорова, С. Г. Гаврина, Л. И. Ройзензона, В. П. Жукова, Н. М. Шанского, А. М. Эмировой и других (Антонова, Бредис, Владимирова и др., 2020). Самыми выдающимися отечественными паремиологами являются Г. Л. Пермяков, С. Д. Мастепанов, В. М. Мокиенко, М. А. Черкасский. В 70-х гг. стали появляться первые дефиниции термина 
в актуальном значении. В последние годы было написано множество работ, посвященных именно определению термина «паремия» (Шайхуллин, 2017).

Пословицы и поговорки ученые и исследователи относят к паремиям, которые изучает и классифицирует такой раздел филологии, как паремиология (Шайхуллин, 2017). На данный момент уже имеется множество исследований в данной научной области, однако не существует единого точного определения понятия «паремия».

Для достижения цели исследования были поставлены следующие задачи: сопоставить основные единицы паремиологии в русском (понятия «пословица» и «поговорка») и испанском (“refrán”, “dicho”, “proverbio”) языках; определить ономастический статус агионимов; изучить классификацию, функции и особенности агиоантропонимов; описать роль и значение религии как компонента культуры носителей языка в ходе развития испанского государства. Основными методами исследования стали следующие: метод наблюдения, описания, сравнения, классификации, метод анализа и синтеза теоретического материала, метод исторического анализа и конкретизации.

Теоретической базой послужили работы в области фразеологии: Г. Л. Пермякова, В. И. Даля, А. В. Киселева; в области паремиологии: М. А. Черкасского, Е. Н. Антоновой, М. А. Бредис, Т. Е. Владимировой, Л. Н. Гишкаевой, Е. Е. Иванова, Е. И. Зиновьевой, Д. Д. Комовой, О. В. Ломакиной, А. С. Макаровой, В. М. Мокиенко, Н. Ю. Нелюбовой, Е. К. Николаевой, Е. И. Селиверстовой, Н. Н. Семененко, Ф. Г. Фаткуллиной, Р. Х. Хайруллиной, Ц. Цао, А. В. Ледневой, А. Н. Мартыновой, В. В. Митрофановой, Г. Г. Матвеевой, М. А. Серегиной, Н. Н. Меньшаковой, М. А. Рыбниковой, А. И. Соболева, 3. К. Тарланова, Т. А. Шайхуллина, L. A. Rodríguez Manzano, D. P. Zarate; в области имен собственных: А. В. Суперанской, Г. Ю. Сызрановой, Н. В. Подольской, И. В. Бугаевой; в области изучения агионимов: И. В. Бугаевой, А. С. Лаврентьевой, Ю. В. Кореневой, Á. Iglesias Ovejero. Teoретическая значимость работы заключается в подробном описании понятия «паремия» и его характеристик, сопоставлении основных единиц паремиологии (пословиц и поговорок), выявлении места агиоантропонимов в ономастике, анализе особенностей испанских паремий с компонентом-агиоантропонимом.

Практическая значимость работы: материалы и результаты исследования могут быть использованы в гуманитарных вузах при подготовке и проведении лекционных и семинарских занятий по курсам «Языкознание», «Лексикология», «Практика устной и письменной речи», «Стилистика», а также в рамках спецкурсов «Фразеология», «Ономастика», «Антропонимика», «История и теория фольклора». Полученные данные также могут найти применение при создании учебников, учебных и учебно-методических пособий по лингвистическим дисциплинам.

\section{Основная часть}

Имя собственное, оним, собственное существительное - это «слово, служащее индивидуальным обозначением лиц и животных, географических и астрономических объектов, учреждений, органов и т.п.» (Жеребило, 2010, с. 119). Все имена собственные являются объектом изучения такого раздела лингвистики, как ономастика. Все многообразие онимов классифицируется на виды по называемому объекту: антропонимы (онимы, обозначающие имена, фамилии, отчества, псевдонимы и прозвища), топонимы (географические названия), зоонимы (имена животных, птиц), мифонимы (имена людей, животных, различных объектов, в реальности никогда не существовавших), космонимы (названия космических объектов) и т.д. (Сызранова, 2013).

В отдельный вид онимов выделяют имена собственные, имеющие характеристику сакральности, святости, которые называются агионимами. Все агиографические имена собственные образуют ономастическое поле слов, объединенных характеристикой святости (Бугаева, 2007).

Согласно определению Словаря русской ономастической терминологии, агионим - имя святого (Подольская, 1988). Соответственно, автор словаря рассматривает понятие «агионим» как один из видов антропонимов наряду с именем, фамилией, прозвищем, как имя собственное, принадлежащее святому.

Из-за этимологии термина «агионим» (agios - священный, onyma - имя) филолог, исследовательница сакральной ономастики И. В. Бугаева считает, что данное понятие имеет более широкое значение и рассматривает его как любой оним, связанный с сакральностью. По И. В. Бугаевой (2006), агионим - это «словосочетание, служащее для именования лиц или объектов, на которых почивает благодать Божия или святость через чин прославления или освящения».

И. В. Бугаева (2007) впервые разработала классификацию сакральных (связанных со святостью) онимов и выделила понятие «агиоантропоним», которое определяется как «апеллятивно-антропонимический комплекс, служащий для номинации прославленных христианских святых» (с. 238). По мнению И. В. Бугаевой, понятие «агионим», которое является обозначением всех сакральных имен собственных, является гиперонимом, родовым понятием по отношению к термину «агиоантропоним», который означает именно имена прославленных святых.

И. В. Бугаева (2007) выделяет 6 видов сакральных имен собственных: теоним - имя Бога (Бог, Господь, Царь Небесный, Божие (-ий, -ия), Спаситель, Dios, Cristo. Стоит отметить, что имя Богородицы И. В. Бугаева и Ю. В. Коренева также относят к данной группе, так как Богородица как мать Иисуса Христа скорее относится к Богу, чем к святым), агиоантропоним (имена святых - Сергий Радонежский, Николай Чудотворец, Sап Fermín, Santa Ángela de la Cruz, San Anastasio), агиотопоним (географические названия с использованием агиоантропонимов или агиохронотопонимов - города Борисоглебск, Сан-Франциско, Santiago de Compostela, улицы Воздвиженка, Сретенка, Покровка), экклезионим (названия соборов, храмов и монастырей, часовен - 
храм Иверской иконы Божией Матери, la Concatedral de Santa María de Guadalajara, la Catedral de Santa María de Teruel), эортоним (названия церковных праздников - Троица, Воздвижение, Сретение, Conmemoración del Santísimo Nombre de Jesús, Fiesta de Santa María Virgen, Madre de la Compañía de Jesús, Día de la Santísima Cruz), иконим (наименования икон - Калужская икона Божией Матери, Икона Божией Матери «Знамение», San Antonio de Padua, la Moreneta). Стоит отметить, что, если рассматривать контекст именно католической церкви, к иконимам будут относиться имена собственные, обозначающие не только названия икон, то есть живописных изображений святых, но и их скульптурные изображения, что не распространено в православной традиции.

Наиболее обширные группы агионимов составляют теонимы и агиоантропонимы, так как «житие святого в православной концептосфере и антропоцентрично, и христоцентрично одновременно» (Коренева, 2013, с. 14). Если не брать в расчет теонимы, ядро классификации сакральных имен собственных составляют агиоантропонимы, так как они являются ономаосновой для практически всех остальных сакральных наименований: так или иначе большинство агионимов связаны с именами святых.

Рассмотрим основные функции агиоантропонимов. Первичная функция любого антропонима - функция идентификации. Она позволяет идентифицировать носителя конкретного имени среди других. Апеллятивная функция заключается в том, что агиоантропонимы могут употребляться в том числе как обращение (в молитвах, коплах) (копла - жанр испанского фольклора, написанный в восьмисложнике (четырехстопный хорей) с рифмовкой четных строк (https://dle.rae.es/copla)). Благодаря кумулятивной функции в семантике слова отражаются знания и представления носителей лингвокультуры о данном феномене. В агиоантропонимах отражается и сохраняется информация об актуальной действительности, они являются носителями огромного пласта информации о культуре народа. Оценочно-характеризующая функция проявляется в семантике агиоантропонима, которая вызывает у людей определенное эмоциональное отношение, благодаря чему агиоантропонимы часто употребляются в устойчивых словосочетаниях, выразительных сравнениях. Благодаря символической функции имя святого может обозначать эталон какого-либо качества, какой-либо человеческой черты, быть воплощением определенного идеального образа. Например, великомученик Георгий Победоносец воплощает образ бесстрашного человека, так как по преданию он победил дракона, который в христианстве воплощает одну из ипостасей дьявола. Также агиоантропонимы выполняют экспрессивную функцию: используются в качестве сравнения (например, “más bonito que un San Luis” или “asarse como San Lorenzo” - Лаврентий Римский был подвергнут пыткам и заживо изжарен на решетке). Агиоантропонимы могут выполнять комическую функцию и использоваться с целью достижения комического эффекта, зачастую в шуточных паремиях, например, с помощью использования сарказма (“sentarle a uno una cosa como a Cristo un par de pistolas” - «подходить друг другу, как пара пистолетов Христу»). Также необходимо отметить текстообразующую функцию, которая проявляется в том, что агиоантропоним непосредственно формирует, организует структуру и композицию текста (Лаврентьева, 2017).

И. В. Бугаева (2007) считает нужным отметить, что антропоним и агиоантропоним - не тождественные понятия с точки зрения структуры. Антропоним может быть отдельно именем, фамилией, отчеством, псевдонимом, в то время как агиоантропоним - обязательно составная единица, состоящая из двух элементов как минимум (например, Преподобный Серафим Саровский). Количество имен собственных, которые могут привлекаться для наименования, в любом языке ограничено, поэтому для дифференциации святого используются дополнительные имена собственные. Имен святых, состоящих из двух элементов, немного, так как уже спустя некоторое время после возникновения христианства появилась необходимость их дифференцировать. Чаще всего агиоантропоним имеет трехкомпонентную структуру и состоит из чина святости, имени и какого-либо дифференциатора. Третьим элементом, дифференциатором, могут выступать номинаторы (мученик Марианн диакон), дескриптор - прилагательное в полной или краткой форме (святой Василий Великий), локализатор (Ксения Петербургская, Матрона Московская, преподобная Мария Египетская), агномен прозвище (великомученик Георгий Победоносец), когномен - фамилия (святой Николай Кочанов), этноним принадлежность к этнической общности (Максим Грек). Фамилия как дифференциатор появилась в православии только в XX веке, в то время как в католицизме фамилия в именовании святых использовалась в ходе всей истории церкви. Встречаются агиоантропонимы из четырех (святитель Макарий, митрополит Московский) или пяти (святитель Григорий Двоеслов, папа Римский) компонентов.

Другое различие состоит в том, что в отличие от антропонима чаще всего в состав агиоантропонима не входит отчество. Отчество в структуре именования святого появилось в русском языке только после прославления Царственных страстотерпцев в 2000 году (например, страстотерпец Николай II Александрович) (Бугаева, 2007).

Агиоантропонимы имеют лишь один референт и являются «сингулярными», в то время как другие антропонимы могут иметь неограниченное число референтов (Лаврентьева, 2017). Например, имена Jorge или Diegо могут принадлежать множеству людей, а агиоантропонимы Beato Jorge de San José и San Diego de Alcalá отсылают только к одному референту (католические святые).

Существует позиция, согласно которой антропонимы не обладают сигнификатом. Это положение подвергается возражениям со стороны ученых, так как многие антропонимы всегда несут в себе часть культуры народа. Можно утверждать, что агиоантропонимы всегда будут иметь понятие, содержание, или сигнификат, так как данные имена собственные содержат определенную лингвокультурную информацию (Коренева, 2013).

Еще одна особенность заключается в том, что имена собственные, принадлежащие обычным людям, могут складываться в именования в различных вариациях: имя, имя и отчество, имя и фамилия, а также фамилия, имя и отчество. Имена святых также могут образовывать синонимические ряды от официальных имен 
до более разговорных (например, преподобный Сергий Радонежский, игумен Радонежский, Сергий Радонежский, преподобный Сергий) (Бугаева, 2007).

Имена собственные, обладающие характерными дифференциальными признаками референта, к которому они отсылают, называются также именами прецедентными. По Ю. Н. Караулову (2007), «имя прецедентное» обладает такими чертами, как широко известный как прошлым, так и настоящему поколению сверхличностный характер, эмоциональная и информативная значимость, многократное употребление в речи носителем данной лингвокультуры. Многие испанские имена святых широко известны всем испанцам, часто употребляются носителями в речи, так как существует множество паремий, содержащих агиоантропонимы, а также несут в себе коннотативную нагрузку, то есть имеют эмоциональную, оттеночную окраску. Следовательно, можно назвать испанские агиоантропонимы «именами прецедентными» (Лаврентьева, 2017).

Агионимы являются важнейшим носителем лингвокультуры. Они хранят в себе большое количество в первую очередь религиоведческой, а также культурологической и исторической информации. В религиозной картине мира ономастическое пространство, связанное со святостью, едино для представителей всех народов и носителей разных языков, если они исповедуют общую религию. И. В. Бугаева (2009) пишет, что «агиоантропонимы занимают центральное место в религиозной модели мира» (с. 38). В агиоантропонимах отражается видение мира, система ценностей, общерелигиозные представления приверженцев какой-либо религии или какой-либо из ветвей одной религии, к какому народу они бы ни относились. В агиоантропонимах мы видим общее отношение верующих к каким-либо феноменам истории религии, что проявляется в выборе эпитетов (дифференциаторов), используемых с именами святых. Но и с другой стороны, специфика оценочного ореола каждого агиоантропонима варьируется в зависимости от принадлежности верующих к определенной народности (Лаврентьева, 2017). Носители различных лингвокультур и даже различные территориальные группы наделяют, казалось бы, единые церковные имена собственной спецификой благодаря тому, что разные народы и социальные группы обладают собственной исторической и лингвокультурологической картиной мира (Суперанская, 2007).

На данный момент самая распространенная по численности приверженцев конфессия в Испании - католичество, которое является одним из ответвлений христианства (Centro de Investigaciones sociológicas, 2014).

Первые сведения о христианстве мы наблюдаем в I в. в ранних христианских источниках, согласно которым Пиренейский полуостров посетил с евангельской миссией апостол Павел (Талалай, Токарева, 2018).

B V в. к доминированию на Средиземноморье пришла Византийская империя. Византийский император Константин I принял христианство еще в 312 году.

В эпоху Великого переселения народов на территорию в V веке приходят германские племена, которые вытесняют ослабевшую Римскую империю. Вестготы, которые будут управлять страной несколько столетий, к тому времени уже приняли христианство в форме арианства. Арианство было одним из первых течений христианства, которое утверждало сотворенность (тварность) Бога-Сына и антитринитаризм, или неединосущность Бога-Сына с Богом-Отцом. Потомки иберо-римлян не поддерживали попыток Леовигильда достичь религиозного единства на основе арианства. Сын Леовигильда Реккаред в 587 году принимает католичество, примеру которого затем последовали все вестготы (http://www.toletanus.ru/?id=bibliotheca.read.2.Ispanija).

Арабское завоевание Испании на время положило конец католичеству. Началось повсеместное обращение в ислам. Оно не было принудительным, но несло определенные послабления для населения (например, отмену налогов), что должно было сподвигнуть население на обращение в другую религию.

Отвоевание испанских земель, получившее в истории название «Реконкиста», было не только политическим, но и важным религиозным процессом. Освобождение от арабского завоевания воспринималось как победа христианской веры на территории современной Испании. Кульминация Реконкисты пришлась на правление Католических королей Фердинанда II Арагонского и Изабеллы I. Достижение брачного союза между Католическими королями фактически ознаменовало единение королевства Испании, и католичество было провозглашено господствующей религией.

Ради достижения в государстве католического единства эти монархи требовали от своих подданных обращения в католичество, а все, кто отказывался это делать, должны были покинуть страну. После этого и до настоящего времени католичество, будучи ветвью христианства, является преобладающей по численности приверженцев конфессией в Испании, хоть и после принятия Конституции 1931 года Испания была провозглашена светским государством. Современная Испания также является светским государством, а в Конституции закреплена свобода вероисповедания. Сейчас около 69\% всего населения Испании относят себя к католикам (Centro de Investigaciones sociológicas, 2014).

В католичестве существует разделение праведников на собственно святых и блаженных. Причисление праведника к лику святых - канонизация, а причисление к числу блаженных - беатификация. В отношении блаженного устанавливается только местное почитание, а не общецерковное, хоть блаженный и считается пребывающим на небесах. Беатификация является первым этапом канонизации (Чурина, 2008).

Нельзя дать точный ответ на вопрос о количестве святых в католической церкви, речь идет о тысячах канонизированных праведников. Святых в привычном понимании можно разделить на beatos/beatas (блаженные, прошедшие этап беатификации) и santos/santas (канонизированные святые, собственно причисленные к лику святых). Среди именно испанских канонизированных святых стоит выделить San Isidro Labrador (Исидор Мадридский, Исидор Крестьянин, Исидор Батрак, покровитель Мадрида и всего крестьянства, обладал даром преумножать урожай, помогал бедным крестьянам), Santo Domingo de Guzmán (Святой Доминик де Гусман, основатель ордена проповедников, или ордена доминиканцев, является покровителем Бургоса), San Ignacio 
de Loyola (Игнатий де Лойола, создатель ордена иезуитов, покровитель Страны Басков), Santa Teresa de Ávila или Santa Teresa de Jesús (Тереза Авильская, Тереза Иисусова, монахиня-кармелитка, реформатор кармелитского ордена, причислена к Учителям Церкви, является покровительницей Авилы), San José de Calasanz (Иосиф де Каласанс, Иосиф Каласанский, основатель первой в Европе христианской школы, является покровителем христианских школ), Santa Ángela de la Cruz (основательница ордена Compañía de las Hermanas de la Cruz, посвященного помощи бедным и больным), San Josemaría Escrivá (Хосемария Эскрива, основатель католической организации «Опус Деи»), San Vicente Ferrer (Викентий Феррер, Винсент Феррер, один из великих проповедников Средневековья, покровитель Валенсийского сообщества), San Francisco Javier (Франциск Ксаверий, миссионер, один из основателей ордена иезуитов, покровитель Наварры) (Martínez, 2004). Не только все автономные сообщества обладают покровителями из числа святых, свой покровитель есть у каждого испанского города. Покровитель Испании - Santiago el Mayor, Santiago de Zebedeo или Jacobo de Zebedeo (Иаков Зеведеев, Иаков Старший или Сантьяго). Он является одним из двенадцати апостолов, ближайших учеников Иисуса Христа, и единственным апостолом, чья смерть описана в Новом Завете. Также является покровителем города Сантьяго-деКомпостела и еще 16 других стран и городов (https://www.santopedia.com/santos/santiago-el-mayor-apostol).

Имена испанских святых, испанских мучеников эпохи гонений на христиан почитаются как Западной, так и Восточной церковью и являются важной частью католического и в целом христианского наследия. Огромен вклад святых уроженцев Испании в католическую и христианскую культуру и христианскую мысль; а испанские богословы, агиографы и историки церкви способствовали развитию христианской литературы и сохранили опыт испанского католичества с самого начала его истории, который сейчас является достоянием католичества и христианства в целом.

\section{Заключение}

В современной лингвистике понятие паремия трактуется как единица языка, обладающая чертами лаконичности, афористичности, общеупотребительная и носящая дидактический характер. К паремиям принято относить пословицы и поговорки, однако некоторые филологи и исследователи относят к ним еще афоризмы, сказки, басни (носители фольклора). В испанском языке основными единицами паремиологии являются понятия “dicho”, “refrán”, “proverbio”. Под пословицей в русском языке понимают законченное умозаключение с использованием иносказания, иногда с рифмой, носящее устный общеупотребительный характер и содержащее поучение, наставление. «Поговорка» означает образное выражение, метафору, которая может быть элементом, частью пословицы. В испанском языке понятия “refrán” и “dicho” можно соотнести с пословицей и поговоркой соответственно на основе схожести их характеристик. “Refrán” представляет собой завершенное суждение, носящее поучительный характер, а “dicho” - меткое выражение, сравнение на основе метафоры. В испанском языке к паремиям относится также понятие “proverbio”, которое можно сопоставить с афоризмом, так как это законченная мысль, носящая поучительный характер и изначально принадлежащая известному человеку или мудрецу, а затем перешедшая в общее употребление.

Агиоантропонимы являются элементом ономастического пространства и определяются как единицы языка, обозначающие имена прославленных христианских святых. Смежные понятия «агионим» и «агиоантропоним» не тождественны, т.к. «агионим» определяется как любое имя собственное, связанное со святостью, сакральностью, а «агиоантропоним» - более узкое понятие, обозначающее имя святого, т.е. это сакральный антропоним.

Ключевыми характеристиками агиоантропонимов являются, как правило, трехкомпонентная структура (минимум два компонента: обычно чин святости + имя + дифференциатор), наличие только одного референта, в отличие от других антропонимов, а также прецедентность, что означает сверхличностный характер, значимость референта и, следовательно, агиоантропонима для определенной лингвокультуры и частое употребление в речи, например в паремиях.

Присутствие агиоантропонимов в паремиологическом фонде испанского языка объясняется тем, что религия в ходе всего развития испанского государства существовала в тесной взаимосвязи с культурой и историей народа, составляя значительную их часть. Таким образом, паремии с компонентом-агиоантропонимом отражают лингвокультурную картину мира. Дальнейшее исследование паремий с агиоантропонимом открывает перспективы изучения картины мира носителей испанского языка через религиозную ее составляющую, а также позволит определить, как в лингвокультуре носителей отражаются определенные религиозные смыслы.

\section{Источники | References}

1. Антонова Е. Н., Бредис М. А., Владимирова Т. Е., Гишкаева Л. Н., Иванов Е. Е., Зиновьева Е. И., Комова Д. Д., Ломакина О. В., Макарова А. С., Мокиенко В. М., Нелюбова Н. Ю., Николаева Е. К., Селиверстова Е. И., Семененко Н. Н., Фаткуллина Ф. Г., Хайруллина Р. Х., Цао Ц. Паремиология без границ: монография / под ред. М. А. Бредиса, О. В. Ломакиной. М.: РУДН, 2020.

2. Бугаева И. В. Агионимы в ономастическом пространстве русского языка. 2006. URL: http://www.portalslovo.ru/philology/45446.php

3. Бугаева И. В. Агионимы в православной среде: структурно-семантический анализ: монография. М., 2007. 
4. Бугаева И. В. Сакральная ономастика в религиозном дискурсе // Этнолингвистика. Ономастика. Этимология: материалы междунар. конф. (г. Екатеринбург, 8-12 сентября 2009 г.). Екатеринбург: Изд-во Урал. ун-та, 2009.

5. Жеребило Т. В. Словарь лингвистических терминов. Изд-е 5-е, испр. и доп. Назрань: Пилигрим, 2010.

6. Караулов Ю. Н. Русский язык и языковая личность. М.: Изд-во ЛКИ, 2007.

7. Коренева Ю. В. Онимы в концептосфере преподобнического жития // Вестник Московского государственного областного университета. Серия «Русская филология». 2013. № 3.

8. Лаврентьева А. С. Функционирование агиоантропонимов в испанской лингвокультуре: дисс. ... к. филол. н. М., 2017.

9. Подольская Н. В. Словарь русской ономастической терминологии / отв. ред. А. В. Суперанская; АН СССР, Ин-т языкознания. Изд-е 2-е, перераб. и доп. М.: Наука, 1988.

10. Рыбникова М. А. Русские пословицы и поговорки. М.: Изд-во Академии наук СССР, 1961.

11. Суперанская А. В. Общая теория имени собственного. Изд-е 2-е, испр. M.: URSS, 2007.

12. Сызранова Г. Ю. Ономастика: учеб. пособие. Тольятти: Изд-во ТГУ, 2013.

13. Талалай М. Г., Токарева Е. С. Православие в Испании: трудный путь становления и развития // Вестник Православного Свято-Тихоновского гуманитарного университета. 2018. Вып. 82.

14. Чурина И. О. Канонизация и почитание местных святых в истории церкви // Ленинградский юридический журнал. 2008. № 3 (13).

15. Шайхуллин Т. А. Актуальные вопросы паремиологии в русском языкознании // Современный мусульманский мир. 2017. № 2.

16. Centro de Investigaciones sociológicas. Barómetro de abríl, 2014. Avance de resultados. Tabulación por variales sociodemográficas. Estudio no 3021 Abril, 2014. URL: http://datos.cis.es/pdf/Es3021sd_A.pdf

17. Martínez J. A. Los grandes santos españoles. 2004. URL: https://www.abc.es/sociedad/abci-grandes-santos-espanoles200405150300-9621495480558_noticia.html?ref=https:\%2F\%2Fwww.google.ru\%2F

\section{Информация об авторах | Author information}

RU Захарова Людмила Борисовна ${ }^{1}$, к. ист. н., доц.

Захарова Елена Валерьевна ${ }^{2}$

${ }^{1}$ Самарский государственный технический университет

${ }^{2}$ Московский педагогический государственный университет

EN Zakharova Liudmila Borisovna ${ }^{1}, \mathrm{PhD}$

Zakharova Elena Valerievna ${ }^{2}$

${ }^{1}$ Samara State Technical University

${ }^{2}$ Moscow State Pedagogical University

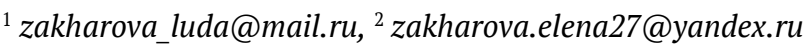

\section{Информация о статье | About this article}

Дата поступления рукописи (received): 18.11.2021; опубликовано (published): 31.01.2022.

Ключевые слова (keywords): паремии; агионимы; агиоантропонимы; лингвокультура; лингвокультурная картина мира; paroemia; hagionyms; agioanthroponyms; linguoculture; linguocultural worldview. 